\title{
Dynamic Modeling and Damping Function of GUPFC in Multi-Machine Power System
}

\author{
Sasongko Pramono $\mathrm{Hadi}^{1}$
}

\begin{abstract}
This paper presents a new dynamic model of multi-machine power system equipped with GUPFC for power system study, and using PSS and GUPFC POD controller some effective control schemes are proposed to improve power system stability. Based on UPFC configuration, an additional series boosting transformer is considered to define a GUPFC configuration and its mathematical model; Phillips-Heffron scheme is used to formulate machine model, and modification of network dealing with GUPFC parameter is carried out to develop a MIMO as well as comprehensive power system with GUPFC model. Genetics Algorithm method was proposed to lead-lag compensation design, this technique provides the parameter controller. The controller produced supplementary signals, the PSS for machine and POD for GUPFC. By applying a small disturbance, the dynamic stability power system was investigated. Simulation results show that the proposed power system with GUPFC model is valid and suitable for stability analysis. The installation of GUPFC without POD decreased the damping oscillation. But, the results show that the presence of GUPFC in power system network provided by PSS and POD controller is very potential to improve system stability. A $66 \%$ overshoot reduction could be reached, it is obtained $12 \mathrm{~s}$ in settling time (shorter), although the rise time become $700 \mathrm{~ms}$ longer. Simulation results revealed that the role of POD controller is more dominant than the PSS, however both PSS and GUPFC POD controller simultaneously present a positive interaction. Phase angle of converter $C, \delta_{C}$ is the most significant control signal POD in oscillation damping.
\end{abstract}

Keywords — genetics algorithm, GUPFC, modeling, multi-machine, POD, PSS, stability

Abstrak-Paper ini menyajikan sebuah model dinamis baru dari sistem tenaga listrik mesin jamak yang dilengkapi dengan GUPFC untuk studi sistem tenaga listrik, dan dengan menggunakan kendali PSS dan GUPFC POD, diusulkan beberapa skema kendali efektif untuk perbaikan dinamika dan stabilitas sistem. Berbasis pada konfigurasi sebuah UPFC, sebuah transformator boosting ditambahkan untuk mendapatkan konfigurasi dan model matematis GUPFC; model Phillips-Heffron digunakan untuk model mesin, dan modifikasi jaringan karena terpasang GUPFC dilakukan untuk memperoleh model sistem lengkap dan berbentuk multi input multi output MIMO. Dengan metode Algoritma Genetika, teknik kompensasi lead-lag diterapkan untuk perancangan parameter kendali dan menghasilkan sinyal kendali tambahan PSS untuk mesin dan POD untuk GUPFC. Stabilitas dinamis sistem diuji melalui pemberian gangguan kecil ke sistem. Hasil simulasi menunjukkan bahwa model sistem tenaga listrik dengan GUPFC terpasang telah dihasilkan dan model ini valid serta cocok untuk analisis stabilitas. Instalasi GUPFC tanpa POD ternyata menurunkan daya peredaman sistem. Selanjutnya, hasil simulasi menunjukkan pula bahwa keberadaan GUPFC di sistem yang telah dilengkapi dengan PSS dan kendali POD sangat berpotensi memperbaiki stabilitas. Simpangan tanggapan mengecil 66\%, waktu keadaan tunak 12 detik (menurun), meskipun waktu bangkit lebih lama 700 mdtk. POD juga telah menunjukkan dominasinya dalam perbaikan stabilitas dibanding PSS, kedua kendali PSS dan POD secara bersamaan menunjukkan interaksi positif. Sudut fase konverter $C, \delta_{C}$ adalah sinyal kendali POD yang paling kuat dalam meredam osilasi.

Kata Kunci-algoritma genetika, GUPFC, pemodelan, mesin jamak, POD, PSS, stabilitas

\section{INTRODUCTION}

$\mathrm{T}$ he investigation of FACTS in power system in the last decade show that the GUPFC, as the latest generation of FACTS devices, it has the least number of investigations compared to the others FACTS configuration such as: SVC, TCSC, STATCOM, SSSC, IPFC and UPFC [1]. The commonly used configuration of a GUPFC (multiline UPFC) consists of three voltage source converters, which are connected through a common DC link capacitor. One converter is connected in shunt and the other two in series in two transmission lines. GUPFC is normally located on a transmission network requiring reactive power, with the primary duty to be power flow control [2-3]. As a FACTS device, GUPFC is mainly used for the increase and control of power flow in steady state operation modes. In steady state study, GUPFC has the ability to adjust the bus voltage, transmission line reactance, and phase angle

Sasongko Pramono Hadi is with Department of Electrical Engineering and Information Technology, FT, Universitas Gadjah Mada, Yogyakarta, 55281, Indonesia. E-mail: sasongko@te.ugm.ac.id. between two buses, either simultaneously or independently.

The secondary function of GUPFC in power system could be stability improvement and oscillation damping [4]. Several studies at limited number have been carried out and reported in some literature using UPFC [5-11] and/or GUPFC model for transient studies [7]. FACTS devices, the GUPFCs especially, due to their rapid response, recently might be able to play a significant role in transient and oscillatory stability improvement. To improve the damping of oscillations in power system, supplementary or additional control signal for GUPFC can be developed and applied to existing devices. These supplementary controls are referred to as Power Oscillation Damping (POD) control [4].

Most of the available literature in UPFC and/or GUPFC usually presents Single Machine Infinite Bus (SMIB) model of power system. It is very difficult to find out papers dealing with the dynamic modeling and stability study of multi-machines power system with GUPFC installed.

The study of power system with FACTS controller, PSS for machine as well as POD for GUPFC, has been conducted using appropriate feedback signal, mostly 
speed deviation. The supplementary control signals are produced to get a better damping due to disturbance. Classical and modern techniques are applied to controller design. Lead-lag compensator method has been used and considerable result have published in [2,5], PI controller was very popular in damping oscillation [6-8]. Recently, heuristic method for optimizing a performance index has been investigated in some references $[6,9]$. These previous studies show that the elaboration of FACTS controller is always interested in investigation of the power system stability.

In order to get significant results of power system dynamic and stability study, it is absolutely needed a suitable dynamic model. Many FACTS devices model have been established and used to power system dynamic and transient stability studies. Most of these models are dealing with SVC, TCSC, STATCOM, SSSC, IPFC and UPFC [1-6, 9-11] in both single and multi machine system. GUPFC model especially in multi machine power system is more complicated and is difficult to meet the paper showing detail process modeling.

The aims of this study is to develop a suitable dynamic model of multi-machine power system equipped with GUPFC, and this study also aims to investigate the damping function of GUPFC in multi-machines power system, by applying POD in GUPFC as well as Power System Stabilizer (PSS) in machines simultaneously. Furthermore, this study is carried out to elaborate the interaction between PSS and POD when disturbances occur in the power system. The presence of GUPFC in the power system network probably influent the effectiveness and efficiency of PSS

\section{METHOD}

In this study, we have five investigation steps as follows:

(1) Establish the system configuration

(2) System dynamic modeling

(3) Control design

(4) Simulation results and discussion

(5) Conclusions draw.

Modeling and oscillation damping of the system installed with an UPFC were presented by $[2,3,11]$ for the reason of effectiveness, we apply a similar system and operating condition (including the data) as the bases of the study. In this study, Genetic Algorithm will be proposed as an optimization tools to parameter control design.

\section{A. System Configuration}

Consider the proposed GUPFC in this study is to be installed in an n-machine power system, the transformer are installed between nodes 1,2 and 3 as shown in Figure 1. This GUPFC consists of an Excitation Transformer (ET), two Boosting Transformer (BT), three three-phases GTO based voltage source converters (VSCs) VSC-E, VSC-B and VSC-C, and a DC link capacitor $\mathrm{C}_{\mathrm{DC}}$. In Figure $1, \mathrm{~m}_{\mathrm{E}}, \mathrm{m}_{\mathrm{B}}, \mathrm{m}_{\mathrm{C}}, \delta_{\mathrm{E}}, \delta_{\mathrm{B}}$ and $\delta_{\mathrm{E}}$ are the amplitude modulation ratios and phase angles of the control signal of each VSC respectively, which are the control signals to the GUPFC.

\section{B. System Dynamic Model}

In this paragraph, the model of two boosting and one excitation transformer, and of the DC links capacitor are first formulated. After that, the network equation are modified considering the GUPFC parameters. Then, the linearised Phillips-Heffron model of a power system machine installed with an GUPFC is established. Finally system with GUPFC model is defined and a schematic diagram will be presented at the end of this paper.

1. GUPFC Model

The GUPFC system model presented in this paragraph contains the model of three main components: excitation, boosting, and capacitor DC link. The installation of 3 converters are: one parallel and two series converters, which is the extension of UPFC model developed in $[2,3,11]$. Assume the resistance and transients of the transformers parameters of the GUPFC are not considered. Applying Park's transformation on excitation and boosting transformer, and regarding the system configuration as presented on Figure 1, we have:

$V_{E t}=j x_{E} I_{E}+V_{E}$

$V_{E t}=j x B I_{E 2}+V_{E B}$

$V_{C t}=j x_{C} I E 3+V_{C}$

The expression of excitation and boosting transformers current in $\mathrm{d}-\mathrm{q}$ axis coordinate system are:

$\bar{I} E=i E d+j i E q$
$\bar{I}_{E_{2}}=i_{B d}+j i_{B q}$
$\bar{I}_{E 3}=i C d+j i C q$

and the excitation and boosting transformers voltage can be written as follows:

$\bar{V}_{E}=\frac{m_{E} v_{D C}}{2}\left(\cos \delta_{E}+j \sin \delta_{E}\right)=\frac{m_{E} v_{D C}}{2} e^{j \delta_{E}}$
$\bar{V}_{B}=\frac{m_{B} v_{D C}}{2}\left(\cos \delta_{B}+j \sin \delta_{B}\right)=\frac{m_{B} v_{D C}}{2} e^{j \delta_{B}}$
$\bar{V}_{C}=\frac{m_{B} v_{D C}}{2}\left(\cos \delta_{C}+j \sin \delta_{C}\right)=\frac{m_{C} v_{D C}}{2} e^{j \delta_{C}}$

And the voltage dynamic in the DC capacitor is:

$\frac{d v_{d c}}{d t}=\frac{3 m_{E}}{4 c_{d c}}\left[\begin{array}{ll}\cos \delta_{E} & \sin \delta_{E}\end{array}\right]\left[\begin{array}{l}i_{E d} \\ i_{E q}\end{array}\right]+\frac{3 m_{B}}{4 c_{d c}}\left[\begin{array}{cc}\cos \delta_{B} & \sin \delta_{B}\end{array}\right]\left[\begin{array}{c}i_{B d} \\ i_{B q}\end{array}\right]$

$+\frac{3 m_{c}}{4 c_{d c}}\left[\begin{array}{cc}\cos \delta_{C} & \sin \delta_{C}\end{array}\right]\left[\begin{array}{l}i_{C d} \\ i_{C q}\end{array}\right]$

\section{Network Equation}

Assume that the network admittance matrix before GUPFC installed into the power system is $\mathrm{Y}_{\mathrm{t}}$ :

$\left[\begin{array}{c}0 \\ 0 \\ \frac{0}{I_{g}}\end{array}\right]=\left[\begin{array}{llll}\overline{Y_{11}} & \overline{Y_{12}} & \overline{Y_{13}} & \overline{Y_{14}} \\ \overline{Y_{21}} & \overline{Y_{22}} & \overline{Y_{23}} & \overline{Y_{24}} \\ \overline{Y_{41}} & \overline{Y_{42}} & \overline{Y_{43}} & \frac{\overline{Y_{34}}}{Y_{44}}\end{array}\right]\left[\begin{array}{l}\overline{V_{1}} \\ \overline{V_{2}} \\ \overline{V_{3}}\end{array}\right]=\overline{Y_{t}}\left[\begin{array}{c}\overline{V_{1}} \\ \overline{V_{2}} \\ \frac{V_{3}}{V_{g}}\end{array}\right]$

where,

$\bar{I}_{g}=\left[\begin{array}{llll}\bar{I}_{g 1} & \bar{I}_{g 2} & \ldots & \bar{I}_{g n}\end{array}\right]^{T}$

$\bar{V}_{g}=\left[\begin{array}{llll}\bar{V}_{g 1} & \bar{V}_{g 2} & \ldots & \bar{V}_{g n}\end{array}\right]^{T}$

When a GUPFC is installed (suppose at bus 1 , in line 1-2 and 1-3), the total current at node 1,2,3 and the network are:

$$
\begin{aligned}
& \bar{Y}_{11}^{\prime} \bar{V}_{11}+\bar{I}_{E 2}+\bar{I}_{E 3}+\bar{Y}_{14} \bar{V}_{g}=0 \\
& -\bar{I}_{E 2}+\bar{Y}_{22} \bar{V}_{2}+\bar{Y}_{24} \bar{V}_{g}=0 \\
& -\bar{I}_{E 3}+\bar{Y}_{33} \bar{V}_{3}+\bar{Y}_{34} \bar{V}_{g}=0
\end{aligned}
$$


$\bar{Y}_{41} \bar{V}_{1}+\bar{Y}_{42} \bar{V}_{2}+\bar{Y}_{43} \bar{V}_{3}+\bar{Y}_{44} \bar{V}_{g}=\bar{I}_{g}$

where $\bar{Y}_{11}^{\prime}, \bar{Y}_{22}^{\prime}, \bar{Y}_{33}^{\prime}$ are obtained by deleting $x_{12}=x_{E 2}$ and $x_{13}=x_{E 3}$ from $\bar{Y}_{11}^{\prime}, \bar{Y}_{22}^{\prime}, \bar{Y}_{33}^{\prime}$. The excitation transformer of GUPFC supposed to be installed at bus 1, and the two boosting transformers in lines between node 1 and 2 and between node 1 and 3 , the network equation can be expressed as:

$\bar{V}_{1}=\bar{V}_{E t}$

$\bar{V}_{2}=\bar{V}_{E t}-j x_{E 2} \bar{I}_{E 2}-\bar{V}_{B t}$

$\bar{V}_{3}=\bar{V}_{E t}-j x_{E 3} \bar{I}_{E 3}-\bar{V}_{C t}$

$\bar{I}_{E}=\bar{I}_{1 E}-\bar{I}_{E 2}-\bar{I}_{E 3}$

Substitution Equation 1 into Equation 7, and then using this result for substitution into Equation 6, we can express the Equation 6 in the form of:

$\bar{I}_{g}=f\left(\bar{V}_{g}, \bar{V}_{E}, \bar{V}_{B}, \bar{V}_{C}\right)$

finally the current can be written as:

$\bar{I}_{g}=\bar{C} \bar{V}_{g}+\bar{F}_{E} \bar{V}_{E}+\bar{F}_{B} \bar{V}_{B}+\bar{F}_{C} \bar{V}_{C}$

Where $\bar{C}, \quad \bar{F}_{E}, \quad \bar{F}_{B}, \bar{F}_{C}$ are network parameter (admittances).

\section{Multi-Machine Model}

The dynamic model of $\mathrm{n}$ machines in the multimachine system can be expressed as:

$$
\begin{aligned}
& \dot{\delta}=\omega_{0} \omega \\
& \dot{\omega}=M^{-1}\left(T_{M}-T_{E}-D_{\omega}\right) \\
& E_{q}^{\prime}=T_{D 0}^{\prime-1}\left[\left(X_{D}-X_{E}^{\prime}\right) I_{D}-E_{q}^{\prime}+E_{f d}\right] \\
& \dot{E}_{f d}=T_{A}^{-1}\left(K_{A} \Delta V_{t}-E_{f d}\right)
\end{aligned}
$$

where system variables and parameters are in $\mathrm{n}$ dimension vector or matrix, example: $\delta=\left[\begin{array}{lll}\delta_{1} & \delta_{2} & \ldots .\end{array}\right.$ $\left.\delta_{n}\right]^{\mathrm{T}}$. At the generator terminal, voltage-current relationship can be expressed as:

$\bar{V}_{g}=\overline{E_{q}^{\prime}}-j X_{D}^{\prime} \bar{I}_{g}-j\left(X_{Q}-X_{D}^{\prime}\right) \bar{I}_{Q}$

Substituting this equation into Equation 8 , it is obtained:

$\bar{I}_{g}=\bar{C}_{d}\left[\bar{E}_{q}^{\prime}-j\left(X_{Q}-X_{D}^{\prime}\right) \bar{I}_{Q}+\bar{C}_{E} \bar{V}_{E}+\bar{C}_{B} \bar{V}_{B}+\bar{C}_{C} \bar{V}_{C}\right]$

where,

$$
\begin{aligned}
& \bar{C}_{d}=\left(\bar{C}^{-1}+j X_{D}^{\prime}\right)^{-1} \quad ; \bar{C}_{E}=\bar{C}^{-1} \bar{F}_{E} \\
& \bar{C}_{B}=\bar{C}^{-1} \bar{F}_{B} \quad ; \quad \bar{C}_{C}=\bar{C}^{-1} \bar{F}_{C}
\end{aligned}
$$

4. Linearised Model

Most of the analysis of power system dynamics and stability and the design of power system controller such as PSS and FACTS based stabilizers have been carried out using linearised model. Linearising the model of $n$ machine power system (Equation 9) around an operating point of the power system will produce a linearised model of power system. By neglecting the internal resistance and sub-transient process of the generator, and when the function of governor is neglected $\left(\Delta T_{M}=\right.$
0, linearizing Equation 9 gives the system equation in the form of vectors and matrices, for example vector:

$\Delta \delta=\left[\begin{array}{llll}\Delta \delta_{1} & \Delta \delta_{2} & \ldots & \Delta \delta_{n}\end{array}\right]^{T}$

$\Delta \dot{\delta}=\omega_{0} \Delta \omega$

$\Delta \dot{\omega}=M^{-1}\left(-\Delta T_{E}-D \Delta \omega\right)$

$\Delta E_{q}^{\prime}=T_{D 0}^{\prime-1}\left[\left(X_{D}-X_{D}^{\prime}\right) \Delta I_{D}-\Delta E_{q}^{\prime}+\Delta E_{f d}\right]$

$\Delta \dot{E}_{f d}=T_{A}^{-1}\left(K_{A} \Delta V_{t}-\Delta E_{f d}\right)$

where,

$\Delta T_{q}=I_{Q} E_{q 0}^{\prime}+I_{Q 0} \Delta E_{q}^{\prime}+\Delta I_{Q}\left(X_{q}-X_{D}^{\prime}\right) I_{D 0}+I_{Q 0}\left(X_{q}-X_{D}^{\prime}\right) \Delta I_{D 0}$

$\Delta V_{T D}=X_{Q} \Delta I_{Q}^{\prime}$

$\Delta V_{T D Q}^{\prime}=\Delta \ddot{E}_{q}^{\prime}-X_{D}^{\prime} \Delta I_{D}$

Using Equation 3 and 11, the expression of current in the $\mathrm{d}-\mathrm{q}$ coordinate system, provide the generator current as a function of state and control variables as follows:

$\Delta I_{d}=Y_{d} \Delta \delta+F_{d} \Delta E_{q}^{\prime}+G_{d} \Delta v_{d c}+H_{E d} \Delta m_{E}+R_{E d} \Delta \delta_{E}+H_{B d} \Delta m_{B}$

$$
R_{B d} \Delta \delta_{B}+H_{C d} \Delta m_{C}+R_{C d} \Delta \delta_{C}
$$

$\Delta I_{q}^{\prime}=Y_{q} \Delta \delta+F_{q} \Delta E_{q}^{\prime}+G_{q} \Delta v_{d c}+H_{E q} \Delta m_{E}+R_{E q} \Delta \delta_{E}+H_{B q} \Delta m_{B}$

$$
R_{B q} \Delta \delta_{B}+H_{C q} \Delta m_{C}+R_{C q} \Delta \delta_{C}
$$

Where Y, F, G, H, R are parameter matrices represent the sensitivity of the current to other variable system. Regrouping these sensitivity factors, we have $\mathrm{K}$ parameters as the coefficients of these equations:

$$
\begin{aligned}
\Delta T_{e}^{*}= & K_{1} \Delta \delta+K_{2} \Delta E_{q}^{\prime}+K_{p d} \Delta v_{d c}+K_{p e} \Delta m_{E}+K_{p d e} \Delta \delta_{E}+K_{p b} \Delta m_{B} \\
& K_{p d b} \Delta \delta_{B}+K_{p c} \Delta m_{C}+K_{p d c} \Delta \delta_{C} \\
\Delta E_{q}^{\prime}= & K_{4} \Delta \delta+K_{3} \Delta E_{q}^{\prime}+K_{q d} \Delta v_{d c}+K_{q e} \Delta m_{E}+K_{q d e} \Delta \delta_{E}+K_{q b} \Delta m_{B} \\
& K_{q d b} \Delta \delta_{B}+K_{q c} \Delta m_{C}+K_{q d c} \Delta \delta_{C} \\
\Delta V_{t}^{\prime}= & K_{5} \Delta \delta+K_{6} \Delta E_{q}^{\prime}+K_{v d} \Delta v_{d c}+K_{v e} \Delta m_{E}+K_{v d e} \Delta \delta_{E}+K_{v b} \Delta m_{B} \\
& K_{v d b} \Delta \delta_{B}+K_{v c} \Delta m_{C}+K_{v d c} \Delta \delta_{C}
\end{aligned}
$$

Linearising Equation 2, machine $\mathrm{i}^{\text {th }}$, is obtained:

$\Delta \dot{v}_{D C}=K_{7} \Delta \delta+K_{8} \Delta E_{q}^{\prime}+K_{c e} \Delta m_{E}+K_{c d e} \Delta \delta_{E}+K_{c b} \Delta m_{B}+K_{c d b} \Delta \delta_{B}$

$K_{c c} \Delta m_{C}+K_{c d c} \Delta \delta_{C}-K_{9} \Delta v_{D C}$

Parameter $\mathrm{K}_{7}, \mathrm{~K}_{8}$ and $\mathrm{K}_{9}$ represent the relationship between $\Delta \mathrm{v}_{D C}^{\prime}$ with $\Delta \delta, \Delta \mathrm{E}_{\mathrm{q}}^{\prime}$ and $\Delta \mathrm{v}_{D C}^{\prime}$ respectively.

Representation these Equation 13 to 16 in the form of state equation, and supposed that state variable vector $\mathrm{x}$ and input variable vector $\mathrm{u}$ containing respectively $\Delta \delta$, $\Delta \omega, \Delta \mathrm{E}_{\mathrm{q}}^{\prime}, \Delta \mathrm{E}_{\mathrm{fd}}, \Delta \mathrm{v}_{\mathrm{dc}}$ and $\Delta m_{E}, \Delta \delta_{E}, \Delta m_{B}, \Delta \delta_{B}, \Delta m_{C}, \Delta \delta_{C}$ signals, the state variable equation is:

$\dot{x}=A x+B u$

The matrix $\mathrm{A}$ is:

$$
\left[\begin{array}{ccccc}
0 & \omega_{0} I & 0 & 0 & 0 \\
-M^{-1} K_{1} & -M^{-1} D & -M^{-1} K_{2} & 0 & -M^{-1} K_{p \delta} \\
-T_{d 0}^{-1} K_{4} & 0 & -T_{d 0}^{\prime-1} K_{3} & -T_{d 0}^{\prime-1} & T_{d 0}^{-1} K_{p \delta} \\
-T_{A}^{-1} K_{A} K_{5} & 0 & -T_{A}^{-1} K_{A} K_{6} & -T_{A}^{\prime-1} & -T_{A}^{-1} K_{A} K_{v \delta} \\
K_{7} & 0 & K_{8} & 0 & -K_{9}
\end{array}\right]
$$


And matrix B is:

$$
\begin{aligned}
& {\left[\begin{array}{ccccc}
0 & 0 & 0 & 0 & 0 \\
-M^{-1} K_{p e} & -M^{-1} K_{p \delta e} & -M^{-1} K_{p b} & -M^{-1} K_{p d b} & -M^{-1} K_{p c} \\
-T_{d 0}^{\prime-1} K_{q e} & -T_{d 0}^{-1} K_{q \delta e} & -T_{d 0}^{\prime-1} K_{q b} & -T_{d 0}^{\prime-1} K_{q \delta b} & T_{d 0}^{-1} K_{q c} \\
-T_{A}^{-1} K_{A} K_{v e} & -T_{A}^{-1} K_{A} K_{v \delta e} & -T_{A}^{-1} K_{A} K_{v b} & -T_{A}^{-1} K_{A} K_{v \delta b} & -T_{A}^{-1} K_{A} K_{v e} \\
K_{c e} & K_{c \delta b} & K_{c b} & K_{c \delta b} & K_{c c}
\end{array}\right.} \\
& \left.\begin{array}{c}
0 \\
-M^{-1} K_{p \delta e} \\
-T_{d 0}^{-1} K_{q \delta e} \\
-T_{A}^{-1} K_{A} K_{v \delta e} \\
K_{c \delta c}
\end{array}\right]
\end{aligned}
$$

According to the above state equation, the block diagram of the system (suppose machine i) can be presented in the Figure 2. (presented at the end of this paper). See Sasongko [12] for the detail calculation of the elements of matrices A and B.

System with $\mathrm{n}$ machines, the dimension of matrix $\mathrm{A}$ is $(5 n, 5 n)$, the interaction among $n$ machines is indicated by each matrix element depending the relation of state variable. The interaction are depicted in Figure 2. The input matrix B with dimension of $(5 n, 6 n)$ show the relationship between each state variable ( 5 variables for each machine) to $6 \mathrm{n}$ control variables (6 for each machine).

\section{PSS and GUPFC POD Controllers Design}

Power system variables such as rotor angle, rotor speed, frequency and electric power can be used to produce a feedback control signal [2-9]. Previous simulation result in [2,5-9] indicate that by using speed deviation signal, we have the significant result in damping oscillation. In this research, to improve the system stability, the control both of machines (PSS) and GUPFC (POD) are designed using speed deviation signal $\Delta \omega$ to produce supplementary signals as control signal. These supplementary signals are fed into excitation system (for electrical loop in machine model, PSS) and supplementary signals $\Delta m_{E}, \Delta \delta_{E}, \Delta m_{B}, \Delta \delta_{B}, \Delta m_{C}, \Delta \delta_{C}$ are fed into GUPFC (for GUPFC model, POD). On the basis of the linearised model, the lead-lag compensation method is applied for the design of PSS and GUPFC damping controller. Genetic Algorithm method is proposed in this study to determine the PSS and POD controller parameter, as have been used in [6] where this technique was applied in others FACTS devices.

1. PSS Design

Lead-lag compensation controller is commonly used for PSS design in the study of dynamics power system. It consists of a gain, a washout block, and one or more stage phase compensation block [13]. $\Delta \omega$ is usually used as the input of this controller, and the output will give a control to excitation system. Instead of a two stage leadlag compensator, we proposed a single stage lead lag PSS. The structure and the parameters of the proposed PSS, SEE Figure 3.

Following reference [14], the common parameter value used for one stage of lead-lag compensator are: $\mathrm{K}_{\mathrm{PSS}}=$ $0.1-50, \mathrm{~T}_{1}=0.2-1.5 \mathrm{~s}, \mathrm{~T}_{2}=0.02-0.15 \mathrm{~s}$ and the wash out parameter $\mathrm{T}_{\mathrm{w}}$ is taken at $10 \mathrm{~s}$. Using Genetic
Algorithm, the fitness function can be defined more precisely in order to get the closed loop eigenvalues are lied in the left hand side of s plane, then the controller gain and it's time constant are determined.

\section{GUPFC POD Design}

The damping function of GUPFC can be demonstrated by applying a GUPFC POD controller, this POD produce additional control signals $\mathrm{u}$, can be $\Delta m_{E}, \Delta \delta_{E}, \Delta m_{B}, \Delta \delta_{B}$, $\Delta m_{C}, \Delta \delta_{C}$ or $\Delta \delta_{C}$. The signal $\Delta \omega$ is also used to produce these each additional control signals, the controller structure and parameters are also designed with a leadlag compensation technique. The structure and the parameter of GUPFC POD controller for each control signal are shown in Figure 4.

Using Genetic Algorithm, the gain and time constant are determined.

\section{Genetic Algorithm}

When the lead-lag compensator is applied to improve the power system stability, some new state variables introduce in the system model. The number of incoming state variable depends on the number of lead-lag compensator stage. The controller parameters are established in order to damp the oscillation. In term of modal analysis, the closed loop eigenvalues have to be shifted to more stable s plane area.

Using Genetic Algorithm, we can assign the dominant closed loop eigenvalues to lie closed to a pre-determined pole having a real part $\sigma_{0}$, the objective function may be defined as follows [15-16]:

$J_{l}=\Sigma\left(\sigma_{0}-\sigma_{i}\right)^{2}$, for $\sigma_{i} \geq \sigma_{0}$

Where $\sigma_{\mathrm{i}}$ is the real part of the $i$ th eigenvalue, and $\sigma_{0}$ is a chosen threshold.

\section{RESUlTS AND DISCUSSION}

\section{A. Dynamic Modeling Result}

The applications of UPFC modeling into multimachine power systems and its damping function were investigated in $[2,3,10]$, following these investigation, in this research, it is adopted the same configuration of system as the case study by adding one series of voltage source converter to get a GUPFC configuration.

According to the development of mathematical model presented in previous chapter, it has already been demonstrated how to build a complete model of power system where a GUPFC installed. The model of GUPFC with 3 VSC was presented first. Secondly, it was developed a power system network where GUPFC installed, and consequently GUPFC's parameter should have characterized the new parameter network. The third step, it was developed linear model of synchronous machines which was obtained by linearising PhillipsHeffron machine model. Finally, it was determined the design of control for power system, PSS for machines and POD for GUPFC. Both controls were designed using lead-lag compensation control scheme.

The entire system model in the form of state variable equation in order to get a flexibility in analyzing power system dynamics was also developed. State equation that is shown in Equation 16 also permits us to develop a Multi Input and Multi Output (MIMO) control scheme. Linear Optimal Control (LOC) scheme could be designed using state variable to produce a supplementary control signal [17]. 
Based on this developed model, model test was conducted by running a numerical simulation on this mathematical model. As mentioned above, this model is modification of Wang's UPFC model depicted in $[2,3,10]$, consequently same data were used, included the second voltage source converter (in series) having similar parameter value as big as the first one. System configuration of this study was as Figure 5.

There were 3 generators, 4 buses, GUPFC was installed in bus no 1 , exciting transformer was installed in parallel at bus no 1 and the series VSC were in the transmission line 1-3 and 1-4. The parameter data of system component ( 2 similar machines and 1 different) is presented in Table 1.

Transformers: $Z_{E}=j 0.1 ; Z_{B}=j 0.1 ; Z_{C}=j 0.1$

Transmission lines: $Z_{13}=j 1.2 ; Z_{24}=j 0.33 ; Z_{C}=j 0.4$

DC-Link: $V_{d c}=2 p u ; C_{d c}=3 p u ; K_{D C}=15.1 ; K_{D C}=0.01 \mathrm{~s}$

Suppose the operating condition $P=1.1 \mathrm{pu}, Q=0.15 \mathrm{pu}$ (each machine), the initial condition of system are:

$\bar{V}_{1 t}=1.0 \angle 9^{\circ} ; \bar{V}_{2 t}=1.0 \angle 5^{\circ} ; \bar{V}_{3 t}=1.0 \angle 0^{\circ}$ and

$m_{E}=1.0233 ; m_{B}=1.104 ; m_{C}=1.104$

$\delta_{E}=26.9^{\circ} ; \delta_{B}=-55.87^{\circ} ; \delta_{C}=-83^{\circ}$

With 3 machines in the network, the dimension of matrix $A$ is $(15,15)$, the interaction among 3 machines is indicated by each matrix element depending the relation of state variable. The interaction are depicted in Figure 2. The input matrix $B$ with dimension of $(15,18)$ show the relationship between each state variable ( 5 variables for each machine) to 18 control variables (6 for each machine).

Considering two dynamic system models, system with neither PSS nor GUPFC model and system with GUPFC without POD controller model, these two models (machine 1) were tested by applying a step of $10 \%$ increase in $\mathrm{P}_{\mathrm{m}}$. With this step signal, we have no significant simulation result, then we have applied some stronger disturbances $(20 \%)$ in order to get more significant oscillations, and the results were as Figure 6. From Figure 6, the $20 \%$ of step function representing a load change, it makes the response (rotor angle) converge to a new operating point (as equilibrium point), however, the rotor speed deviation converges slowly. The responses also show that the mathematical model was firm and can be used in simulation studies. The first 2 curves (rotor angle and speed deviation) are the responses of system with neither PSS nor GUPFC to the disturbance mentioned above; these curves represent the nature of multi-machine power system, showing the dynamics behavior of system variable.

The second 2 curves represent the rotor angle and speed deviation of machine no 1 with GUPFC and without POD control. These responses illustrate the dynamics response of system with GUPFC where the mathematical model containing the model of GUPFC, e.g. one excitation transformer, two boosting transformers and one DC link capacitor. This model is related to model in equation (16) without control, representing the nature of dynamics behavior of elements power system included the GUPFC element. Figure 6 shows clearly the result of model simulation, the presence of GUPFC (without POD) makes the response more oscillate.
Simulation in various operating condition were executed. As the numerical simulation executions were in the acceptable range of operating condition, the convergence of quantitative variable values were always attainted to reasonable measures. It signifies that the model will be suitable and valid for further simulation studies, included the control performance.

\section{B. Numerical Simulation Results}

After the model was validated, the simulation on various scenarios probably encountered in real system was conducted. The damping function of GUPFC was investigated based on the system dynamic response against disturbance, following these four scenarios :

1. Neither PSS nor GUPFC

2. With PSS only

3. With GUPFC POD only

4. With both PSS and GUPFC POD

Considering the system under study as depicted at Figure 1, where the GUPFC is installed at the bus 1, we took only the deviation of rotor speed of machine 1 as the input signal for PSS and POD. By applying Genetic Algorithm to minimize fitness function expressed in Equation 17, while this process subject to some constraints: $\mathrm{K}_{\mathrm{PSS}}=0.1-110, \mathrm{~T}_{1}=0.1-2 \mathrm{~s}$, and $\mathrm{T}_{2}=$ $0.01-0.2 \mathrm{~s}$. The wash out parameter $\mathrm{T}_{\mathrm{w}}$ is taken at $10 \mathrm{~s}$, the controller parameter could be determined, the results as follows: (GA: chosen threshold $\sigma_{0}=-0.3$ ). Table 2 shows the variation of parameter value (gain and time constant), this result indicate that each control signal has different role in damping.

\section{PSS Significance}

The dynamic response of $20 \%$ increase in $\mathrm{P}_{\mathrm{m}}$ are presented in Figure 7. The step was applied in machine 1. Figure 7 shows the system response in three different operating conditions, first in the condition where there is neither PSS nor GUPFC installed, than the second, the system with PSS only where there is no installed GUPFC. The third condition is system with PSS where GUPFC has been installed. The system dynamic responses illustrated in Figure 7 represent the system stability characteristic, e.g. the three responses are damped slowly and have different oscillation frequency. The steady state condition of the rotor angle of generator no 1 converged to 30 degree and this value could be reached in less than $10 \mathrm{~s}$, for only system with PSS. PSS showed the effectiveness in damping oscillation, although GUPFC without POD has been installed.

\section{Damping Function of GUPFC POD}

The simulation result aims to show the role of POD in damping the oscillation of system dynamic response following a disturbance. Figure 8 shows three system responses, the system response for: conventional (neither PSS nor GUPFC), with PSS only and finally with POD scheme. The presence of POD controller makes the oscillation frequency decreasing and it is also shown that the damping function of POD is more significant than the PSS's one. Hence, it can be resumed that there is an improvement of oscillation damping by installing POD.

See Figure 6, 7 and 8. From Figure 6, it is shown that the presence of GUPFC in the network makes the system response more oscillate (less damping), and Figure 7 shows the effectiveness of PSS in damping. When the 
supplementary signal POD is applied, see Figure 8, a considerable damping is shown.

The POD consists of 6 signal, they could contribute damping simultaneously. Investigation have been done for identification of the role of each control signal, there were significant differences among the 6 signals: $\Delta m_{E}$, $\Delta \delta_{E}, \Delta m_{B}, \Delta \delta_{B}, \Delta m_{C}, \Delta \delta_{C}$ the most significant signal was $\Delta \delta_{\mathrm{C}}$ (very good damping). Table 3 shows the contribution of control signal in oscillation damping (fitness function indicates the control effectiveness).

Table 3 shows the performance of each POD signal in damping oscillation, the most significant POD is $\Delta \delta_{C}$ minimum fitness function 348.2, furthermore, we have conducted an analysis using response Figure (not presented in this paper). The complete comparison of the role of PSS and/or POD is shown by Figure 9 that showing 4 oscillation responses.

Regarding Figure 9, it is shown the synergy between PSS and POD; the two system responses (response with PSS and POD and response with POD only) have similar curve, almost coincident but the damping of PSS and POD better than POD only. System responses are more slowly, rise time $(1 \mathrm{~s})$ is longer than before $(0.3 \mathrm{~s})$, but settling time is faster, overshoot decreasing significantly (15 degrees to 5 degrees). Although there is no significant improvement between POD and PSS plus POD, this result shows that there was a positive interaction between PSS and POD.

\section{CONCLUSION}

This paper provides a detailed dynamics modeling of a multi-machine power system equipped with GUPFC as the extension of UPFC configuration. Based on this model, numerical simulation results have demonstrated the validity of this dynamic model. The installation of GUPFC without POD decreased the damping oscillation. The proposed control scheme using lead-lag compensation, PSS for the machines as well as POD controller for GUPFC, were investigated. Using Genetic Algorithm, parameter controller have been determined. The simulation results indicate that the POD was more effective than PSS in damping oscillation. There were a positive interaction between both controllers. Applying PSS and POD, a 66\% overshoot reduction can be reached, it is also obtained $12 \mathrm{~s}$ in settling time (shorter), although the rise time becomes $700 \mathrm{~ms}$ longer. $\delta_{\mathrm{C}}$ is the most significant control signal POD in oscillation damping.

In the future research, based on this new power system dynamic model, numerical simulation with more complex system configuration and their control design could be conducted by enhancing power system network equipped with GUPFC and by applying more advanced controller design.

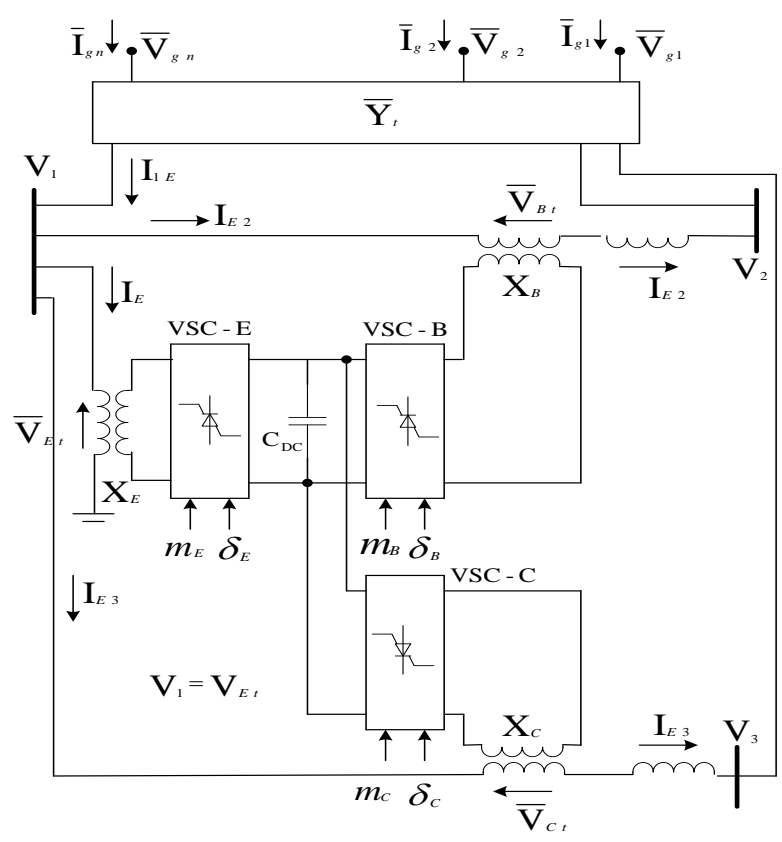

Figure 1. GUPFC configuration 


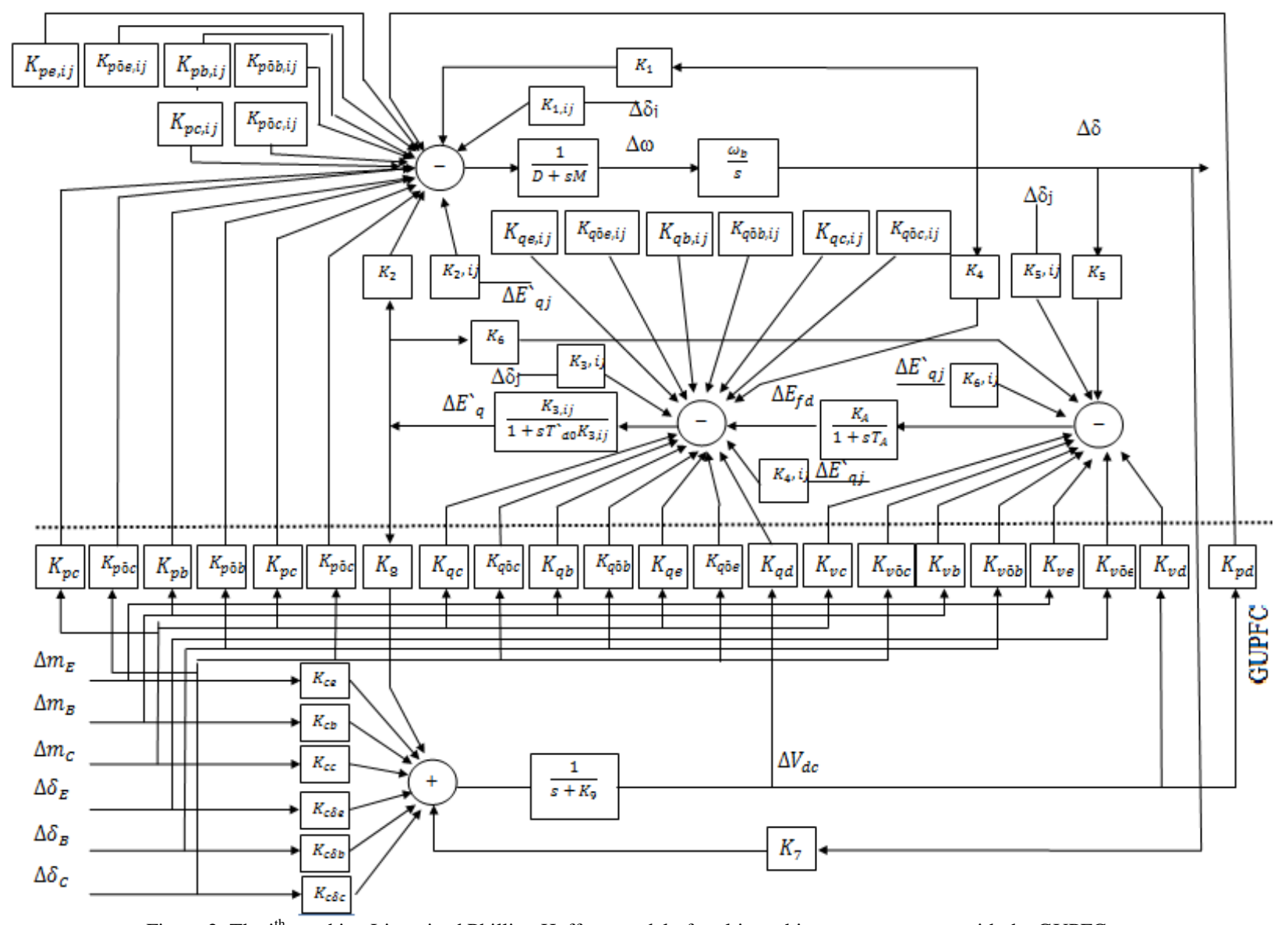

Figure 2. The $\mathrm{i}^{\text {th }}$ machine Linearised Phillips-Heffron model of multi machines power system with the GUPFC.

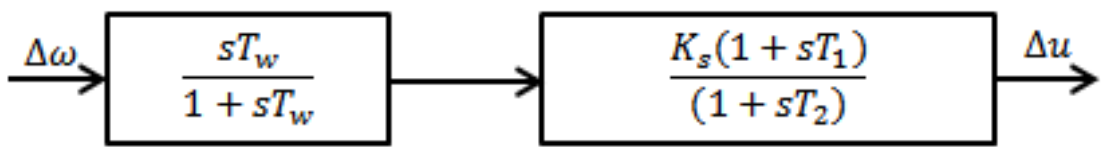

Figure 3. Power system stabilizer structure

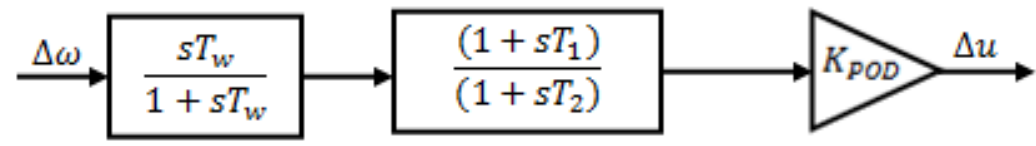

Figure 4. GUPFC POD controller structure

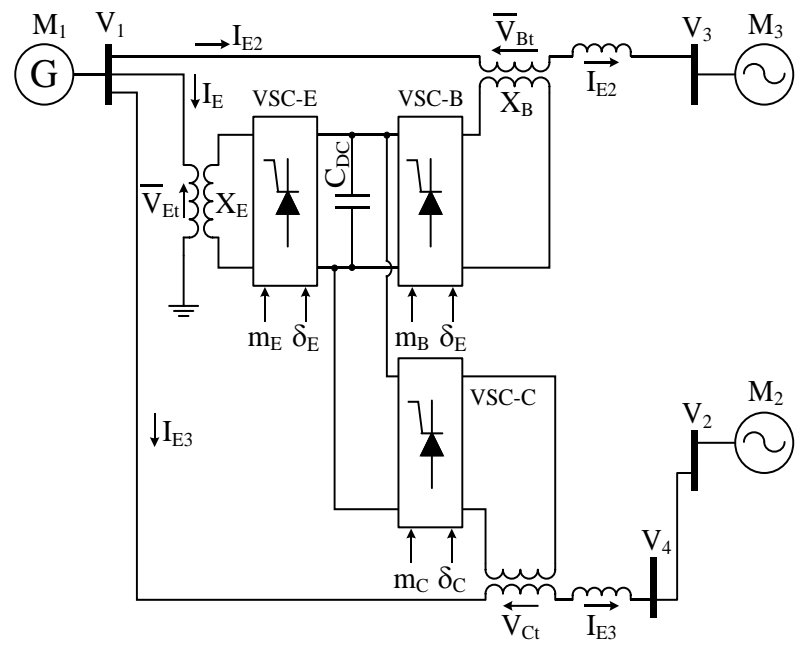

Figure 5. System configuration as case study 


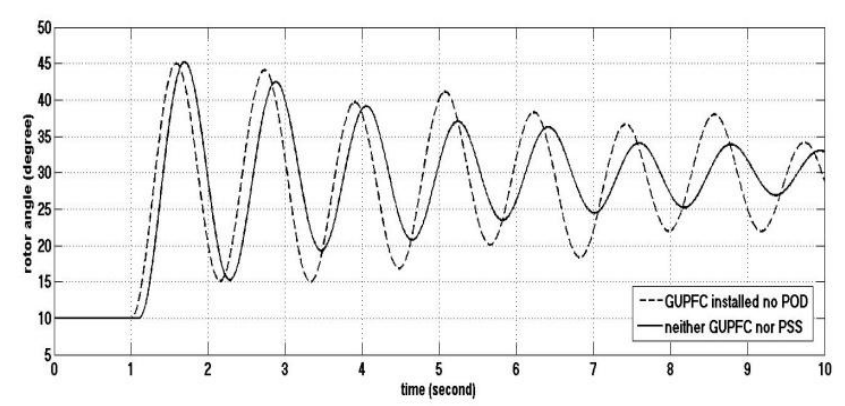

(a)

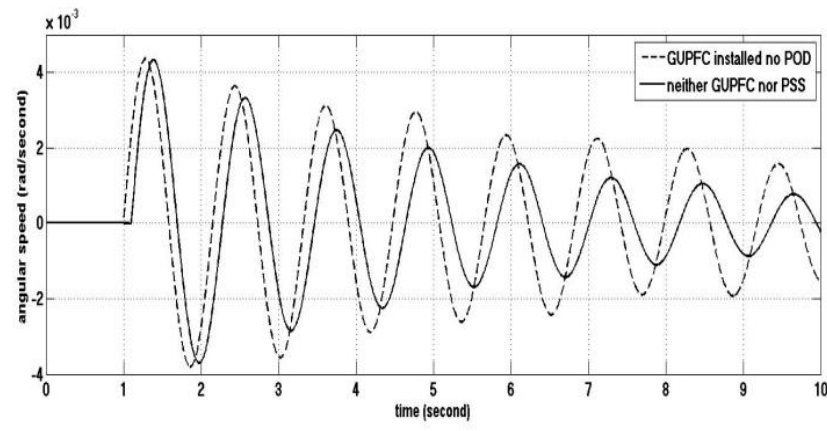

(b)

Figure 6. Simulation results of system model (a) rotor angle (b) angular speed deviation

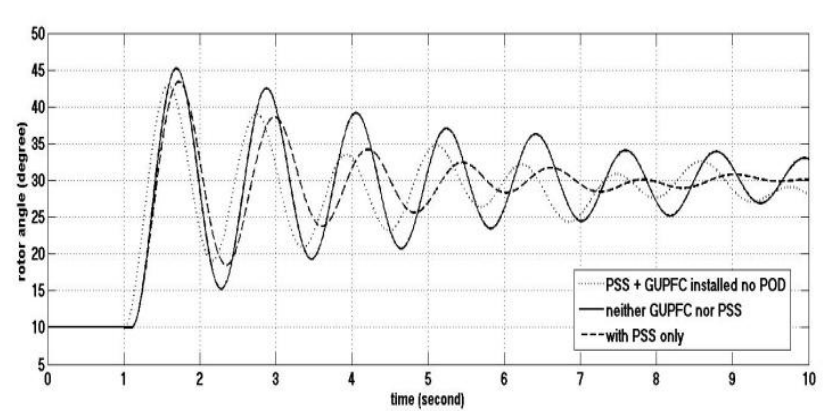

(a)

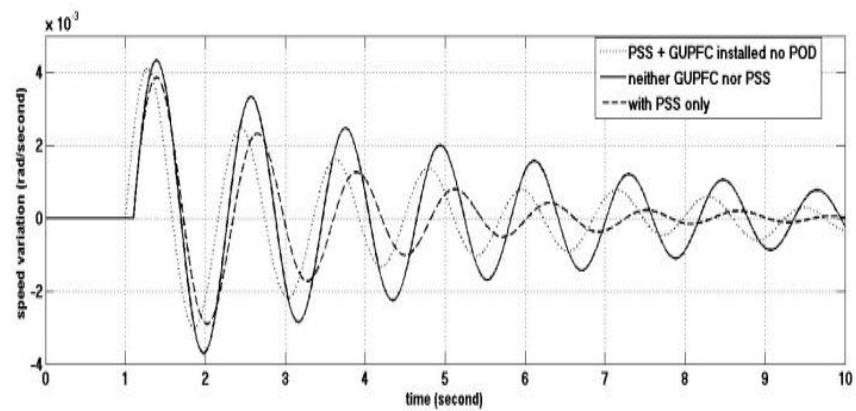

(b)

Figure 7. Rotor angle and angular speed dynamics (a) rotor angle (b) angular speed deviation

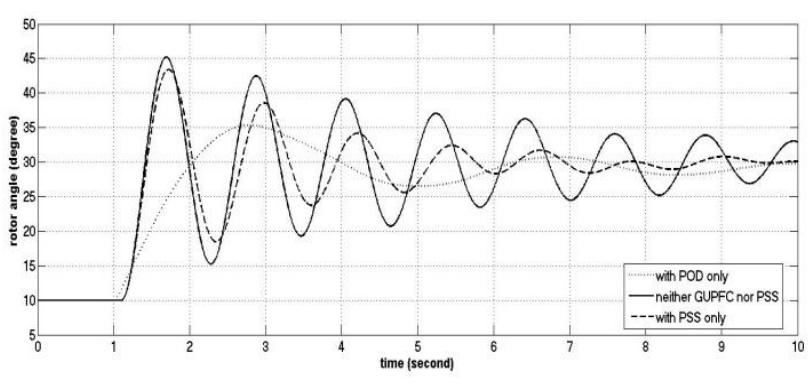

(a)

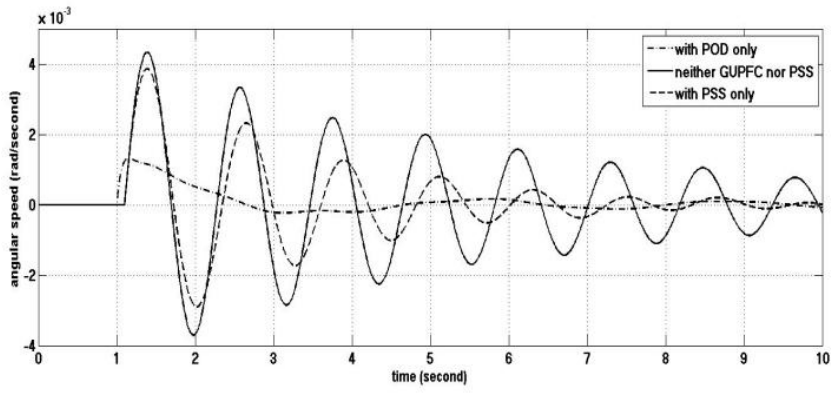

(b)

Figure 8. Responses of system with PSS or with POD (a) rotor angle (b) angular speed deviation

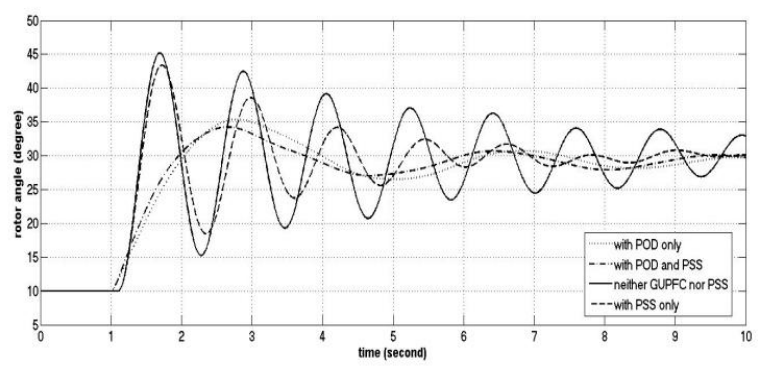

(a)

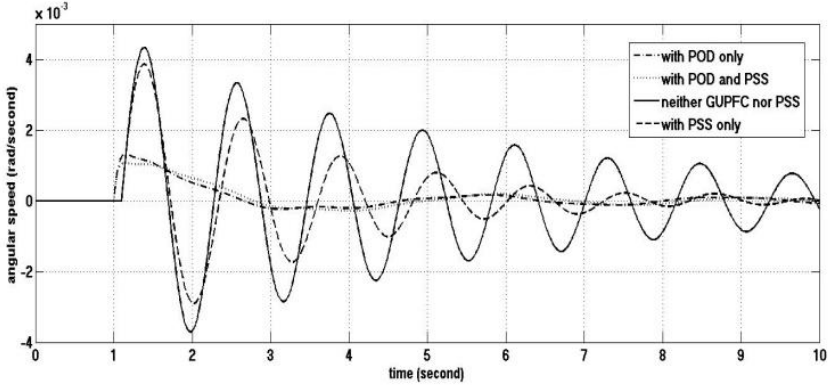

(b)

Figure 9. Comparative response for PSS and GUPFC POD (a) rotor angle (b) angular speed deviation 
TABLE 1.

SYSTEM PARAMETERS

\begin{tabular}{cccc}
\hline Parameter & Machine 1 & Machine 2 & Machine 3 \\
\hline $\mathrm{H}$ & $20.09 \mathrm{~s}$ & $20.09 \mathrm{~s}$ & $118 \mathrm{~s}$ \\
$\boldsymbol{x}_{\boldsymbol{d}}$ & 0.19 & 0.19 & 0.41 \\
$\boldsymbol{x}_{\boldsymbol{s}}^{f}$ & 0.0765 & 0.0765 & 0.173 \\
$\mathrm{D}$ & 0 & 0 & 0 \\
$\mathrm{X}_{\mathrm{q}}$ & 0.163 & 0.163 & 0.33 \\
$T_{\mathrm{s}}^{s}$ & $7.5 \mathrm{~s}$ & $7.5 \mathrm{~s}$ & $7.5 \mathrm{~s}$ \\
$\mathrm{~K}_{\mathrm{A}}$ & 20 & 20 & 100 \\
$\mathrm{~T}_{\mathrm{A}}$ & $0.05 \mathrm{~s}$ & $0.05 \mathrm{~s}$ & $0.01 \mathrm{~s}$ \\
\hline
\end{tabular}

TABLE 2. CONTROLLER PARAMETERS

\begin{tabular}{lllll}
\hline \multicolumn{1}{c}{ Controller } & $\mathrm{K}_{\mathrm{s}} / \mathrm{K}_{\mathrm{POD}}$ & $\mathrm{T}_{1}(\mathrm{~s})$ & $\mathrm{T}_{2}(\mathrm{~s})$ & Remarks \\
\hline POD $\Delta m_{E}$ & 4.999 & 1.090 & 0.12 & GUPFC \\
POD $\Delta \delta_{E}$ & 3.000 & 1.500 & 0.12 & GUPFC \\
POD $\Delta m_{B}$ & 26.760 & 1.299 & 0.12 & GUPFC \\
POD $\Delta \delta_{B}$ & 29.1615 & 1.839 & 0.12 & GUPFC \\
POD $\Delta m_{C}$ & 45.400 & 1.085 & 0.12 & GUPFC \\
POD $\Delta \delta_{C}$ & 108.00 & 1.605 & 0.12 & GUPFC \\
\hline
\end{tabular}

\section{REFERENCES}

[1] C. R. Makkar and L. Dewan, "Transient Stability Enhancement using Robust FACTS Controllers A Brief Tour," Canadian Journal on Electrical and Electronics Engineering, vol.1, no.7, 2010.

[2] H. F. Wang, "Damping function of Unified Power Flow Controller", IEE Proc Gener. Transm. Distrib., vol.146, no.1, pp. 8181-88, 1999.

[3] H. F. Wang, "Application of Modelling UPFC into MultiMachine Power Systems", IEE Proc Gener. Transm. Distrib., vol.146, no.3, pp.306-312, 1999.

[4] S. N. Dhurvey and V. K.Chandrakar, "Performance Comparison of UPFC in Co-ordination with Optimized POD and PSS on Damping of Power System Oscillations," WSEAS Trans on Power System, vol 3, issue 5, pp 287-299, 2008.

[5] Q. Jiang, Z. Zou, Z. Wang, and Y. Cao, "Design of UPFC controller in large-scale power system based on immune genetic algorithm," Trans of the Institute of Measurement and Control, vol.28, no.1, pp $15-25,2006$.

[6] S. A. Taher, S. Akbari, A. Abdolalipour, and Hematti, R., "Design of robust decentralized control for UPFC controller based on structured singular value," American Journal of Applied Sciences, vol.5, no.10, pp 1269 - 1280, 2008.

[7] V. Azbe and R. Mihalic, "Damping of Power System Oscillations with the Application of a GUPFC," in IEEE Bucharest Power Tech Conference Proceeding, 2009.

[8] E. V. Larsen, J. J. Sancez-Gazce, and J. H. Chow, "Concept for Design of FACTS Controller to Damp Power Swing," IEEE Trans. PWRS-2, no.10, pp. 948-956, 1995.
TABLE 3 .

POD SIGNAL DUMPING FUNCTION

\begin{tabular}{cccc}
\hline No & Control signal & Damping function & Fitness function \\
\hline 1 & $\Delta \delta_{\mathrm{C}}$ & very good & 348.2 \\
2 & $\Delta \mathrm{m}_{\mathrm{C}}$ & good & 349.3 \\
3 & $\Delta \mathrm{m}_{\mathrm{B}}$ & fair & 351.6 \\
4 & $\Delta \mathrm{m}_{\mathrm{E}}$ & fair & 352 \\
5 & $\Delta \delta_{\mathrm{B}}$ & poor & 353 \\
6 & $\Delta \delta_{\mathrm{E}}$ & very poor & 358.8 \\
\hline
\end{tabular}

[9] Y. Hashemi, R. Kazemzadeh, M. R. Azizian, and A. Sadeghi, "Simultaneous Coordinated Design of Two-Level UPFC Damping Controller and PSS to Damp Oscillation in MultiMachine Power System," presented in 26th International Power System Conference, Teheran, 2011.

[10] L. H. Hassan, M. Moghavvemi, and H. A. F. Mohamed, "Impact of UPFC-based Damping Controller on Dynamic stability of Iraqi Power Network," Scientific Research and Essays, vol.6, no.1, pp. 136-145, 2011.

[11] H. F. Wang and F. J. Swift, "An Unified Model for the Analysis of FACTS devices in Damping power System Oscillations Part II: Multi-Machine Infinite-Bus Power Systems," IEEE Trans. Power Deliv., no. 2, pp. 941-946, 1992.

[12] P. H. Sasongko, "Power System Dynamics and Stability," Lecture Notes, Gadjah Mada University, Yogyakarta, 2010.

[13] Y. N. Yu, Electric Power System Dynamics, Academic Press, 1983.

[14] P. W. Sauer and M. A. Pai, Power System Dynamics and Stability, Prentice-hall Inc., New Jersey, 1998.

[15] A. Jalilvand, A. Safari, and R. Aghmasheh, Design of State "Feedback Stabilizer for MultiMachine Power System Using PSO Algorithm", in Proceedings of the 12th IEEE International Multitopic Conference, December 23-24, 2008.

[16] A. A. Eldamaty, "Damping Inter-area and Torque Oscillations Using FACTS Devices," A Thesis for the Degree of Doctor of Philosophy, Department of Electrical Engineering University of Saskatchewan Saskatoon, Saskatchewan, 2005.

[17] P. H. Sasongko, M. Talaat, and R. Moret, "More Exact Method for Determining the Optimal Control Weighting Matrices", in Proc. of IASTED Interntl Conf on Electrical Power System, Paris, 1987. 